\title{
Perubahan Tema dan Perspektif dalam Historiografi Asia Tenggara, 1955-2010
}

\author{
Sugeng Prakoso \\ Universitas Negeri Jakarta \\ sprakoso@unj.ac.id
}

\begin{abstract}
This article examines the changes in themes and perspectives in the writing of Southeast Asian history in the period 1955 to 2010. The historiography of the 1950s tended to political history and the dominant view of the external influences of India, China, Islam, and the West on Southeast Asian history. In the 1960s the thematic focus shifted to economic and social aspects along with the emergence of the trend of social sciences approaches in historical studies which was influenced by the Annales School. In the 1980s, with the onset of the linguistic and cultural turns in the social sciences, historians in the region turned to diachronic studies of the formation of identity, mentality, representation and discourse of local knowledge. The shift in perspective also occurred with the emergence of the (Southeast) Asian-centric perspective which saw changes in Southeast Asian society as a result of the dynamic interaction between the region's internal and external forces. Since the end of the 1990s, there has been a tendency for the 'interstices', that is linking the history of the Southeast Asian region with its global historical context, and on the connectivity of historical disciplines with other social-humanities disciplines to build bridges of trans-disciplinary studies.
\end{abstract}

Keywords: Southeast Asia, historiography, political history, social sciences approach, comparative regional history, Annales School, history of mentality

\begin{abstract}
Abstrak: Artikel ini mengkaji perubahan tema dan perspektif dalam penulisan sejarah Asia Tenggara pada periode 1955 sampai 2010. Historiografi dasawarsa 1950-an cenderung pada sejarah politik dan dominannya pandangan ihwal pengaruh eksternal India, Cina, Islam, dan Barat atas sejarah Asia Tenggara. Pada dasawarsa 1960-an fokus tematis bergeser ke aspek ekonomi dan sosial seiring dengan munculnya tren pendekatan ilmu-ilmu sosial yang dipengaruhi oleh Mazhab Annales. Pada dasawarsa 1980-an, dengan menguatnya kajian linguistik dan budaya, sejarawan di kawasan ini beralih ke studi diakronis tentang pembentukan identitas, mentalitas, representasi, dan wacana pengetahuan lokal. Pergeseran perspektif juga terjadi dengan menguatnya perspektif Asia (Tenggara)-sentris yang melihat perubahan-perubahan di dalam masyarakat Asia Tenggara sebagai hasil interaksi dinamis antara kekuatan internal dan eksternal kawasan itu. Sejak akhir dasawarsa 1990-an, muncul kecenderungan pada 'interstisi', yaitu menghubungkan sejarah kawasan lokal Asia Tenggara dengan konteks historis globalnya, dan pada konektivitas disiplin sejarah dengan berbagai disiplin ilmu sosial-humaniora lainnya untuk membangun jembatan kajian transdisipliner.
\end{abstract}

Kata kunci: Asia Tenggara, historiografi, sejarah politik, pendekatan ilmu-ilmu sosial, sejarah komparatif-regional, Mazhab Annales, sejarah mentalitas 


\section{PENDAHULUAN}

Penulisan sejarah Asia Tenggara yang dilakukan oleh sejarawan profesional sebenarnya merupakan bidang kajian yang relatif baru jika dibandingkan dengan, misalnya, kajian sejarah Asia Selatan atau sejarah Asia Timur. Karya pertama tentang sejarah Asia Tenggara, sebagai suatu kajian yang bisa dikatakan lengkap mencakup periode dari masa prasejarah sampai kontemporer, baru muncul pada 1955 melalui buku D.G.E. Hall (1891-1979) A History of South-East Asia. Hall adalah pengajar di SOAS (School of Oriental and African Studies) dan merupakan profesor pertama dalam bidang kajian sejarah Asia Tenggara.

Sebelum munculnya karya Hall tersebut, tulisan-tulisan sejarah mengenai sejarah Asia Tenggara sudah ada, tetapi bukan merupakan tulisan yang bersifat menyeluruh mengenai kawasan Asia Tenggara. Tulisan-tulisan itu membahas suatu wilayah saja (misalnya Jawa, Burma, Kamboja) dan pada umumnya bukan ditulis oleh ahli ilmu sejarah. Terdapat tiga kelompok cendekiawan yang mengkaji sejarah Asia Tenggara masa itu. Pertama, kaum Orientalis dan para ahli arkeologi (khususnya ahli prasasti) yang mempelajari kerajaan-kerajaan kuno untuk merekonstruksi kronologi politik masa lampau. Kedua, para ahli filologi yang mempelajari literatur-literatur pribumi utntuk merekonstruksi 'teks asli'. Ketiga, dalam jumlah yang sangat langka, para sejarawan kompeten yang berkonsentrasi pada sumber sejarah (catatan arsip, surat, memoar) untuk merekonstruksi aktivitas bangsa-bangsa Eropa di kawasan Asia Tenggara sejak abad keenam belas (Ricklefs, 2013: xviii-xix). Sejak terbitnya karya Hall tersebut, penulisan sejarah Asia Tenggara mengalami perkembangan pesat, bukan saja dalam jumlah kajiannya ataupun 
bertambah banyaknya universitas-universitas yang membuka program studi Asia Tenggara, tetapi terutama dalam penggunaan sumber-sumber sejarahnya, pendekatannnya, maupun tema-tema kajiannya.

Perkembangan yang pesat dalam kajian sejarah Asia Tenggara, sejak terbitnya karya Hall pada 1955 itu, menjadi alasan untuk dilakukannya penelitian historiografis ini. Disiplin ilmu sejarah menjadikan historiografi, yaitu 'sejarah (tentang) penulisan sejarah', sebagai suatu bidang kajian yang penting karena tidak jarang perkembangan ilmu sejarah dirangsang oleh tinjauan historiografis ini. Dalam pandangan sejarawan Taufik Abdullah (1997: 41), salah satu hal yang menarik dalam ilmu sejarah adalah kesediaannya untuk sewaktu-waktu melakukan tinjauan terhadap dirinya. Sewaktu-waktu, segala praduga teoretis harus ditinjau lagi dan keampuhan metode harus dipersoalkan lagi.

Artikel ini bertujuan untuk mengidentifikasi tema-tema pokok dan memperlihatkan perubahan-perubahan perspektif dalam penulisan sejarah Asia Tenggara. Pembahasan dibatasi pada sejarah mengenai kawasan Asia Tenggara yang sekarang ini mencakup negara-negara Indonesia, Thailand, Filipina, Malaysia, Vietnam, Kamboja, Laos, Myanmar, Singapura, dan Timor Leste. Periodenya dimulai dari terbitnya karya D.G.E. Hall A History of South-East Asia pada 1955 hingga terbitnya buku A New History of Southeast Asia karya M.C. Ricklefs dkk. (yang merupakan penerus karya Hall tersebut) pada 2010. Pengetahuan historiografis ini berguna bukan saja sebagai tinjauan akademis terhadap penulisan sejarah Asia Tenggara, tetapi secara praktis juga berguna sebagai bahan untuk memperkaya pembelajaran sejarah Asia Tenggara. 


\section{METODE}

Sebagai suatu kajian historiografis, metode penelitian ini mengikuti langkah-langkah dalam penelitian sejarah. Sumber atau data sejarah yang digunakan ada tiga kategori. Pertama adalah artikel-artikel mengenai penulisan sejarah Asia Tenggara yang sudah terlebih dahulu ditulis oleh sejarawan lain. Dalam hal ini adalah artikel yang ditulis John D. Legge berjudul "The Writing of Southeast Asian History" yang terbit dalam buku yang disunting oleh Nicholas Tarling, The Cambridge History of Southeast Asia. Vol. 1. From early times to c. 1800 (Cambridge University Press, 1992). Artikel kedua adalah tulisan Vincent Houben berjudul "Southeast Asian History: The Search for New Perspectives" yang terbit dalam buku yang disunting oleh Cynthia Chou dan Vincent Houben, Southeast Asian Studies: Debates and New Directions (Institute of Southeast Asian Studies, 2006).

Kedua adalah buku-buku sejarah Asia Tenggara yang diterbitkan sepanjang periode yang dikaji dalam penelitian ini, yaitu 1955 hingga 2010. Tetapi, tidak semua buku sejarah Asia Tenggara dijadikan data penelitian karena ini tidak dimaksudkan sebagai semacam survei bibliografis. Hanya sebagian kecil yang dipilih sebagai sumber sejarah, tetapi merupakan karya-karya terpenting (ditulis oleh para sejarawan Asia Tenggara yang paling otoritatif) dan berisi kajian sejarah Asia Tenggara (atau sebagian besar wilayahnya) sebagai suatu kawasan.

Ada lima buku yang menjadi data penelitian ini, masing-masing berupa kajian sejarah yang komprehensif dan terbit pada dasawarsa yang berbeda sehingga dapat menggambarkan perkembangan dalam penulisan

sejarah Asia Tenggara. Kelimanya ialah (1) A History of Southeast Asia 
karya D.G.E. Hall (terbit 1955); Southeast Asia in the Age of Commerce 14501680 karya Anthony Reid (dua jilid, terbit pada 1988 dan 1993); The Cambridge History of Southeast Asia (2 Volume) karya Nicolas Tarling (editor) (terbit 1992); Strange Parallels: Southeast Asia in Global Context, c.800-1830 karya Victor Lieberman (dua jilid, terbit pada 2003); dan A New History of Southeast Asia karya M.C. Ricklefs dkk (terbit 2010). Selain lima buku tersebut, ditambahkan juga sebagai data penelitian ini buku Southeast Asia in World History karya Craig A. Lockard (terbit 2009).

Ketiga adalah artikel resensi buku yang terbit di berbagai jurnal ilmiah yang mengulas kelima buku tersebut di atas yang menjadi data penelitian ini. Seringkali satu buku diresensi oleh begitu banyak orang, misalnya buku Southeast Asia in the Age of Commerce karya Reid. Banyaknya resensi terhadap buku tersebut menunjukkan betapa besar pengaruh yang dibawakan oleh buku ini dalam mengubah arah penulisan sejarah Asia Tenggara pada periode-periode berikutnya. Selain buku Reid, buku kumpulan tulisan yang disunting oleh Nicholas Tarling, The Cambridge History of Southeast Asia, juga mendapatkan banyak ulasan dari berbagai kalangan sejarawan yang menaruh minat pada kajian Asia Tenggara.

Data yang terkandung dalam sumber sejarah tersebut selanjutnya dianalisis untuk menghasilkan tema-tema pokok dan perubahanperubahan perspektif dalam penulisan sejarah Asia Tenggara. Selanjutnya, interpretasi perubahan-perubahan metodologis tersebut dapat digunakan untuk mengidentifikasi karakteristik utama dalam perkembangan penulisan sejarah Asia Tenggara pada periode 1955 sampai 2010. 
Hasil penelitian mengenai penulisan sejarah Asia Tenggara periode 1955 - 2010 ini dituliskan secara kronologis ke dalam dua subperiode yang didasarkan atas perubahan pendekatan (approach) yang digunakannya. Dua subperiode itu adalah 1955 - 1988 (1988 adalah tahun terbit Southeast Asia in the Age of Commerce yang mengindikasikan secara kuat penggunaan pendekatan baru dalam kajian sejarah Asia Tenggara) dan subperiode 1988 - 2010 (2010 adalah tahun terbit A New History of Southeast Asia yang juga mengindikasikan penggunaan pendekatan baru yang lebih bersifat kultural-antropologis dan bersudut pandang pribumi). Pada setiap subperiode tersebut, perkembangan dalam penulisan sejarah Asia Tenggara diukur dengan terjadinya pergeseran tema-tema pokok dan perubahan perspektifnya. Sebagai pengantar terhadap periode yang dikaji dalam penelitian ini, dipaparkan juga perkembangan penulisan sejarah Asia Tenggara pada periode sebelum terbitnya buku D.G.E. Hall A History of South-East Asia, atau periode sebelum 1955.

\section{HASIL}

\section{Historiografi Asia Tenggara Sebelum Karya D.G.E. Hall}

Perkembangan sejarah Asia Tenggara sebagian besar mengikuti tren dalam disiplin sejarah umum, meskipun seringkali dengan jeda waktu tertentu. Sebelum Perang Dunia II, sejarah non-Barat hanya diperlakukan sebagai perpanjangan dari sejarah Barat. Sejarah kolonial dhasilkan dalam jumlah besar dan kualitas yang bervariasi, yang sebagiannya untuk melayani kebutuhan pejabat kolonial untuk memperoleh kronologi dasar dari wilayah yang mereka kuasai. Mereka menekankan peran sentral orang Eropa sebagai agen perubahan dan mentransmisikan representasi simbolik superioritas Barat atas Timur. Dengan tekanan mereka pada 
kronologi dari peristiwa-peristiwa dan orientasi pada kepentingan kolonial, sejarah resmi ini terintegrasi secara kuat ke dalam historiografi Eropa pada saat itu (Houben, 2006: 144).

Menurut John D. Legge (1992: 3-4), sebelum Perang Dunia II studi sejarah Asia Tenggara dapat dibagi menjadi dua kategori besar. Generasi pertama pertama adalah mereka yang memiliki keprihatinan besar terhadap sejarah awal kawasan ini yang diwujudkan dengan upayaupaya untuk mengumpulkan berbagai sumber arkeologis, epigrafis dan sastra, dan sekumpulan besar data-data kronologis yang belum teruji. Kedua, perhatian diberikan kepada kegiatan-kegiatan penyelidikan kaum kolonial Eropa sejak abad ke-16 untuk menciptakan, secara bertahap, kerajaan koloni yang mendukung penguasaan mereka atas aspek komersial dan teritorial di Asia Tenggara.

Jenis penyelidikan pertama sangat dibatasi oleh sifat data atau bukti yang tersedia. Pada konteks ini, bukti historis tertua tentang Asia Tenggara menunjuk pada tarikh sekitar abad kelima Masehi. Ada peninggalan-peninggalan yang berasal dari sebelum periode tersebut yang memungkinkan untuk penyelidikan mengenai budaya prasejarah asli kawasan ini. Alat-alat batu dan artefak tulang memberikan beberapa bukti periode palaeolitik dan neolitik. Dari sini diperoleh beberapa kesimpulan tentatif tentang pengembangan pertanian dan tentang apakah itu merupakan perkembangan asli atau diperkenalkan dari luar.

Sedangkan untuk jenis penyelidikan kedua mengenai sejarah Asia Tenggara, diperoleh sumber-sumber yang jauh lebih banyak. Sementara mahasiswa peminat kajian sejarah Asia Tenggara generasi awal hanya memiliki bukti-bukti yang sangat fragmentaris dan terbatas, siswa dari 
periode yang kemudian mampu memanfaatkan sumber yang luas yang disediakan oleh tulisan-tulisan pengamat Eropa dan oleh arsip kolonial dari bangsa-bangsa Barat-Portugis, Spanyol, Belanda, Prancis, Inggris, dan Amerika. Bagi orang Eropa, keberadaan tulisan dan arsip tersebut dianggap dapat memberikan landasan yang lebih pasti bagi pengetahuan sejarah Asia Tenggara, meskipun interpretasi dan perspektif yang mereka gunakan selalu bias dengan kepentingan mereka sendiri.

Lebih lanjut, Legge (1992: 4-7) menjelaskan bahwa dari segi perspektif yang digunakan, dua kategori penyelidikan tersebut berbagi ciri tertentu. Ciri pertama ialah kecenderungan umum para sejarawan untuk fokus hanya pada bagian-bagian tertentu dari Asia Tenggara daripada mengembangkan perspektif tentang kawasan itu secara keseluruhan sebagai objek studi. Ini barangkali tidak terhindarkan karena saat itu mereka terfokus pada upaya mempelajari kekuasaan imperiumimperium di kawasan itu, seperti Hindia Belanda, Malaya Inggris, Indocina Perancis.

Ciri kedua adalah kecenderungan para sarjana untuk melihat bahwa sejarah Asia tenggara itu dibentuk oleh pengaruh-pengaruh eksternal ke wilayah tersebut daripada sebagai produk dari dinamika internal. Ini sebagian merupakan konsekuensi dari pola pendidikan yang mereka peroleh dari banyak sarjana baik dalam Indologi atau Sinologi, yang cenderung mengarahkan mereka untuk melihat Asia Tenggara dari salah satu perspektif tersebut. Tetapi, itu mungkin juga merupakan konsekuensi dari sifat sumber sejarah yang tersedia. Saat itu terhimpun banyak buktibukti arkeologis, epigrafis dan arsitektur yang bersesuaian dengan periode ketika pengaruh budaya India terlihat jelas (dalam bahasa dan 
paleografi di prasasti) dan detail dekoratif dari sisa arsitektur, juga dalam ide-ide agama Hindu dan Budha dan dalam bentuk-bentuk artistik lainnya seperti difusi epik Sanskerta, Ramayana dan Mahabharata. Begitu banyaknya bukti-bukti pengaruh India itu sehingga banyak orang melihatnya sebagai hasil emigrasi India, dan kolonisasi, atau penakluka, dan menyebut Asia Tenggara sebagai 'Further India' atau 'Greater India'.

Pemikiran yang menekankan pentingnya faktor luar Asia Tenggara (eksogen) tersebut bukan hanya mengarahkan sumbernya ke India dan Cina, tetapi juga terhadap peradaban Barat, khususnya periode sejak abad ke-16. Pemikiran ini diwakili oleh istilah 'Indianisasi', 'Cinaisasi', dan 'Westernisasi', tiga pola historis jangka panjang yang sangat menonjol dalam kajian sejarah Asia Tenggara. Secara lebih khusus, kajian-kajian akademis era sebelum Perang Dunia II itu telah memberi tekanan sebagai 'agen' kepada India lebih daripada pengaruh Cina. Secara empiris, ini tidak sepenuhnya tidak akurat karena sebagian besar bukti benar-benar mendukung pengaruh-pengaruh budaya India di hampir setiap aspek kehidupan di hampir seluruh Asia Tenggara. Ini termasuk agama, sistem penulisan, sastra, konsep tentang waktu, gagasan kepemimpinan, otoritas dan legitimasi, konsepsi alam semesta, dan seni (Aung-Thwin \& Hall, 2011: 5-6).

Ciri ketiga dari studi Asia Tenggara periode pra-Perang Dunia II adalah bahwa hampir seluruhnya adalah hasil kerja para sarjana luar Asia Tenggara: Eropa, Timur Tengah, dan Asia. Pada abad kesembilan belas dan kedua puluh sejumlah sarjana pribumi Asia Tenggara muncul, tetapi orang-orang seperti R.Ng. Perbatjaraka dan Hoesein Djajadiningrat di Hindia-Belanda India, U Tin di Burma, Tran Van Giap di Vietnam, dan 
Pangeran Damrong di Thailand mereka sendiri adalah produk pendidikan Barat dan sarjana yang dididik dalam tradisi internasional modern (Legge, 1992:10).

Itulah karakteristik dari studi di Asia Tenggara pada periode praperang: berfokus pada bagian-bagian daripada keseluruhan, dan melihat berbagai peristiwa di Asia Tenggara sebagai hasil dari pengaruh eksternal. Cara pandang tentang sejarah Asia Tenggara yang seperti itu kemudian mengalami perubahan yang sangat mendasar antara tahun 1942 dan 1945 semasa pendudukan Jepang. Para sejarawan Asia Tenggara yang muncul pasca Perang Dunia II hadir dalam perspektif yang sepenuhnya berbeda dari masa lalu. Mereka memiliki harapan yang berbeda, keasyikan yang berbeda dan menemukan jawaban yang berbeda untuk pertanyaan yang berbeda. Dan mereka hadir dalam jumlah yang jauh lebih besar dari sebelumnya (Legge, 1992:14-15).

Sedikit berbeda dengan kategorisasi Legge, dalam kata pengantar buku A New History of Southeast Asia, Ricklefs (2013: xviii) mengatakan bahwa sebelum pertengahan abad ke-20 terdapat tiga kelompok besar cendekiawan yang mengkaji masa lalu Asia Tenggara. Terdapat tiga kelompok cendekiawan yang mengkaji sejarah Asia Tenggara masa itu. Pertama, kaum Orientalis dan para ahli arkeologi (khususnya ahli prasasti) yang mempelajari tulisan-tulisan di atas batu dan logam dari kerajaan-kerajaan kuno dan seringkali mengkombinasikannya dengan sumber-sumber luar-terutama literatur Cina klasik-untuk untuk merekonstruksi kronologi politik masa lampau. Kedua, para ahli filologi yang mempelajari literatur-literatur pribumi untuk merekonstruksi 'teks asli' (secara hipotetis). Ketiga, para sejarawan kompeten yang 
berkonsentrasi pada sumber sejarah yang biasanya dikaji para sejarawan masa itu: catatan arsip, surat, memoar dan semacamnya. Sumber-sumber semacam ini dalam kasus Asia Tenggara umumnya adalah catatan-catatan kolonial dalam bahasa Eropa. Jadi, seorang sejarawan terlatih yang menggunakan pembahasan sumber sejarah baik dari sumber pribumi maupun sumber luar adalah makhluk langka. Hall sendiri berupaya untuk bekerja dengan cara ini, tetapi sumber-sumber bahasa Burma yang digunakannya sangat terbatas.

Lebih lanjut, Ricklefs (2013: xix) menyatakan bahwa jumlah departemen atau program studi di universitas yang mefokuskan diri dalam bidang Kajian Asia Tenggara juga terbatas (tetapi kemudian tumbuh dengan cepat dalam waktu 20 tahun sesudah Perang Dunia II). Pada 1950 satu-satunya universitas yang memiliki Professor Sejarah yang menhkaji Asia Tenggara adalah SOAS dengan Hall sebagai kepalanya. Terdapat pula kajian di Leiden dan Paris, tetapi sedikit sekali hasil kajian ini yang sesuai dengan ide kita di masa kini tentang pekerjaan sejarawan. Meskipun demikian, di Universitas Cornell tumbuh sebuah program baru yang tidak lama kemudian menjadi pusat disiplin ini. Universitasuniversitas lain segera menyusul seperti AmerikaSerikat dan Australia. Khusus di Australia, Univeritas Monash dan Universitas Nasional Australia menjadi pusat kajian sejarah Asia Tenggara. Ketika bangsabangsa baru Asia Tenggara mulai terbentuk, wajar jika kajian terhadap sejarahnya sendiri juga berkembang di universitas-universitasnya walau dapat dikatakan bahwa pada saat itu kajian mereka terpaksa mengikuti agenda politik dengan cara yang tidak dapat diterima para sejarawan professional. 


\section{Dari Hall ke Era Pendekatan Ilmu Sosial (1955-1988)}

Kajian akademis sejarah Asia Tenggara yang pertama dan utama adalah karya D.G.E. Hall yang berjudul A History of South-East Asia yang terbit pada 1955. Karya Hall tersebut, meskipun menggambarkan dirinya hanya sebagai "garis besar, dipadatkan, dan disederhanakan secara berlebihan di banyak bagian" (Hall, 1955: v), adalah pencapaian besar, mendasarkan diri pada karya rinci dari sarjana lain dan mencerminkan pengetahuan tentang isu-isu kritis perdebatan di antara mereka. Selain mendesak agar Asia Tenggara dipelajari sebagai daerah yang 'layak dipertimbangkan dalam dirinya sendiri' dan bukan sekadar sebagai bayang-bayang di balik sejarah peradaban besar India, Cina, atau Barat, ia tidak menawarkan pendekatan konseptual atau metodologis baru sendiri. Tetapi dalam menyatukan berbagai hasil penelitian yang ada, ia menyediakan semacam inventarisasi per negara berdasarkan kajian-kajian yang ada saat itu.

Asia Tenggara karya Hall berkaitan dengan bangsa-bangsa dan negara-negara di Semenanjung Indo-Cina dan Kepulauan Indonesia. Hall memulai pembahasannya dengan topik rekonstruksi spekulatif budaya 'Austro-Asiatic' dan menutupnya di tahun 1950, yaitu data terakhir yang bisa dikumpulkan Hall saat itu. Tentu saja itu adalah upaya besar dalam bahasa Inggris untuk menyajikan wilayah itu sebagai kajian sejarah tersendiri, yang bukan sekadar bagian dari kajian sejarah Cina, India, atau Barat.

Pada dasawarsa-dasawarsa berikutnya, 1960-an dan 1970-an, sejarah sebagai disiplin ilmu sangat dipengaruhi oleh munculnya ilmu-ilmu sosial yang ingin menemukan keteraturan dalam perilaku orang-orang dan 
perkembangan masyarakat. Oleh karena itu para sejarawan mulai mengklasifikasikan berbagai peristiwa untuk memvalidasi proses dan struktur yang pada gilirannya dapat memberikan jenis kajian sejarah yang lebih 'obyektif'. Tren ini dipicu oleh para sejarawan yang tergabung dalam sebuah kelompok pemikiran sejarah yang disebut 'mazhab Annales'. Orang yang pertama kali melakukan studi dengan metode sejarah total adalah seorang sejarawan Perancis Fernand Braudel. Ia bercerita tentang dunia Mediteranian pada masa Raja Philip II dari Spanyol, raja yang berkuasa pada paruh kedua abad ke-16. Mazhab Annales Perancis memberi ruang yang besar pada penggunaan pendekatan (neo)-Marxis yang mereka praktikkan secara luas. Menentang cara pandang kajian sejarah hermeneutis tradisional yang berpusat pada peristiwa dan kronologi linear, fokus sejarawan yang berpikiran sains sosial ini adalah pada struktur dan proses, termasuk konteks dan demografi fisik-geografis. Konsep 'longue duree' dan 'civilization materielle' sangat penting bagi pendekatan kelompok Annales. Dalam pendekatan Annales itu, sejarawan ekonomi mengumpulkan serangkaian data kuantitatif, sedangkan yang disebut perspektif materialis-historis menekankan pada mode produksi (Houben, 2006: 142).

Munculnya pendekatan ilmu sosial dalam kajian sejarah tersebut juga memengaruhi penulisan sejarah Asia Tenggara. Hal ini terjadi bukan semata karena tren yang dibawa oleh mazhab Annales tersebut, tetapi juga dilatarbelakangi munculnya negara-negara baru di kawasan Asia Tenggara sehingga diperlukan pendekatan baru sebagai bagian dari penciptaan identitas mereka: persepsi baru tentang masa lalu mereka, persepsi yang melampaui intrusi kekuatan-kekuatan Barat dan 
menemukan akar sebelumnya dalam pola-pola budaya yang lebih tua. Efeknya jelas, baik dalam perluasan pengaturan kelembagaan untuk studi Asia dan perubahan dalam pendekatan dan metode penelitian. Dalam beberapa kasus ini mengambil bentuk 'kajian wilayah' (area studies) di mana metode dari berbagai ilmu sosial-sosiologi, antropologi, ilmu politik, ekonomi-bersama dengan sejarah, sastra dan filsafat, disatukan untuk mempelajari suatu bidang atau tema tertentu (Legge, 1992: 15). Dalam kasus lain, perubahan tersebut mengambil bentuk "pendekatan baru terhadap subjek dengan lebih memperhatikan tema dan arus sejarah daripada kepada individu dan peristiwa". Tujuannya ialah untuk menawarkan kajian sejarah Asia Tenggara yang didasarkan atas "kerangka kerja analitis dan bukan sekadar himpunan fakta untuk membangkitkan kesadaran akan kesatuan dalam keragaman" (Tarling, 1978).

Secara lebih khusus, tren dari pendekatan ilmu sosial terhadap studi sejarah ini lebih mengarah pada pendekatan sosiologis. Sebagai contoh, studi Sartono Kartodirdjo tentang gerakan perlawanan pedesaan dapat dianggap sebagai upaya awal untuk menerapkan teori sosiologis ke sumber-sumber sejarah (Kartodirdjo, 1966). Penulisan sejarah dengan pendekatan Mazhab Annales, khususnya generasi pertama mazhab ini, juga sangat menonjol dalam dua volume Southeast Asia in the Age of Commerce karya Anthony Reid. Karya ini mengikuti Mazhab Annales dalam penggunaan konsep struktur dalam peristiwa sejarah, seperti pembahasannya mengenai budaya material dan organisasi sosial. (Penjelasan lebih mendalam mengenai karya Reid ini akan dibahas pada bagian berikutnya). 
Meskipun menjadi berbeda dalam hal subjek dan perspektif dan dalam banyak kasus telah berpindah dari perspektif kolonial ke perspektif pasca-kolonial, tetapi sejarah Asia Tenggara tetap mengikuti tren utama dalam sejarah Barat. Sayangnya hal itu tampaknya tidak terlalu mendapatkan perhatian dari kalangan sejarawan di luar lingkaran spesialis kawasan Asia Tenggara karena kontennya dianggap terlalu spesifik untuk diperhitungkan oleh sejarawan umum Barat.

\section{Di Bawah Hegemoni Mazhab Annales (1988-2010)}

Setelah era D.G.E. Hall dan kemudian munculnya pendekatan ilmu sosial dalam kajian sejarah pada umumnya, bidang kajian sejarah Asia Tenggara menjadi semakin berkembang ke arah sejarah total ala Mazhab Annales. Perkembangan ini sebenarnya hanyalah sebuah konsekuensi logis dari perkembangan serupa di level sejarah global yang sudah dibahas pada subjudul sebelumnya.

Generasi dasawarsa 1960-an hingga awal 1980-an telah melihat perluasan penulisan yang luar biasa dalam kajian sejarah Asia Tenggara, tetapi historiografi Asia Tenggara masih belum matang, dalam arti bahwa beberapa aspek telah dikembangkan dengan cukup baik, tetapi aspek yang lainnya belum. Literatur sejarah yang berasal dari kawasan ini menjadi lebih substansial dan lebih canggih, yang banyak di antaranya membahas perihal negara atau budaya tertentu, tetapi masih banyak juga kesenjangan intensitas maupun kualitas studi sejarah yang terjadi di antara satu negara dan negara lain. Oleh sebab itu, diperlukan sejumlah ahli sejarah kawasan ini yang dapat membantu menyatukan semuanya dan dengan demikian meletakkan fondasi dan menunjukkan jalan untuk 
upaya penelitian lebih lanjut menuju sejarah Asia Tenggara yang lebih bercorak regional dan multitema (Tarling, 1992: xiii-xiv).

Sejarawan Asia Tenggara pertama dengan visi baru itu, yang dengan karyanya telah mengubah secara signifikan cara pandang dan pendekatan generasi sejarawan berikutnya terhadap kajian sejarah kawasan ini, adalah Anthony Reid. Melalui dua jilid buku Southeast Asia in the Age of Commerce yang terbit pada 1988, Reid berusaha menerapkan metodologi Mazhab Annales untuk menyusun sejarah kawasan tersebut. Reid (2011: xxx) berambisi menulis 'sejarah total' Asia Tenggara dengan mengadopsi pendekatan sejarah sebagaimana yang dilakukan oleh Fernand Braudel dalam kajiannya mengenai kawasan Mediterania. Tujuannya adalah untuk menyampaikan sebuah 'sejarah utuh' yang di dalamnya peperangan, dinasti kerajaan, dan pedagang asing tidak lagi menjadi prioritas melebihi masalah makanan, kesehatan, dan hiburan bagi orang awam.

Hanya berselang empat tahun setelah terbitnya buku Reid, sejarawan Asia Tenggara lainnya, Nicholas Tarling, menerbitkan buku kumpulan tulisan (antologi) sejarah Asia Tenggara yang sangat komprehensif dengan mengikuti (setidaknya dalam sebagiannya) gaya pendekatan Mazhab Annales sebagaimana yang telah digunakan oleh Reid. Penerbitan buku berjudul The Cambridge History of Southeast Asia ini dilatarbelakangi kenyataan bahwa, sebagaimana dinyatakan sendiri oleh Tarling dalam prakata buku tersebut, "Ada beberapa sejarah baik di Asia Tenggara; ada juga beberapa sejarah baik dari negara-negara tertentu; tetapi mungkin tidak ada sejarah yang berangkat dari basis regional dan mengambil pendekatan regional" (Tarling, 1992: xiv). Kata Tarling lebih 
lanjut, para penulis yang diundang untuk berkontribusi bagi buku tersebut mengakui bahwa mereka sering menemukan diri mereka melampaui rentang karya yang diterbitkan yang telah membuat mereka terkenal. Namun, sejarah yang baru memberi mereka kesempatan untuk memperluas ke bagian-bagian lain wilayah dan mengadopsi pendekatan komparatif regional.

Buku The Cambridge History of Southeast Asia ini terdiri dari dua volume tebal. Pada volume pertama ada tulisan sebelas sejarawan Asia Tenggara membagi pembahasan menjadi dua periode yang luas: dari prasejarah ke 1500, dan dari 1500 hingga sekitar 1800, berfokus pada empat pokok bahasan utama: negara, masyarakat, agama, dan ekonomi. Buku kedua, yang membahas periode abad ke-19 dan ke-20, menyatukan banyak materi dalam upaya untuk menyajikan Asia Tenggara sebagai sebuah kawasan dan bukan sekadar menyajikan sebuah kelompok masyarakat atau negara. Dengan banyak kandungan informasi, liputan bibliografis yang kaya, dan pengindeksan yang luas, buku ini dimaksudkan untuk melayani berbagai kalangan pembaca sebagai sumber referensi pertama.

Buku ketiga mengenai sejarah Asia Tenggara yang bercorak komparatif regional adalah dua jilid tebal Strange Parallels: Southeast Asia in Global Context, c. 800-1830 karya Victor Lieberman. Berfokus pada Asia Tenggara daratan (berkebalikan dengan buku Reid yang berfokus pada Asia Tenggara kepulauan), buku ini mengetengahkan beberapa upaya Lieberman untuk menghubungkan sejarah kawasan ini dengan sejarah global. Volume pertama buku ini, yang bersubjudul 'Integration on the Mainland: Southeast Asia in Global Context, c.800-1830' (Studies in 
Comparative World History) berfokus pada proses konsolidasi politik dan budaya di tiga cekungan sungai utama di daratan Asia Tenggara dari abad kesembilan hingga abad kesembilan belas Sedangkan volume kedua, yang bersubjudul 'Mainland Mirrors: Europe, Japan, Cina, South Asia, and the Islands', mengambil perbandingan eksplisit Asia Tenggara dengan bagian lain Eurasia, membandingkan Prancis, Rusia, Cina, dan Jepang. Secara garis besar, sebagaimana dikatakan oleh Lieberman, studi dua jilid Strange Parallels ini membahas apa saja yang menjadi kecenderungan jangka panjang utama dalam sejarah politik, budaya, dan ekonomi pra-kolonial Asia Tenggara; dan bagaimana sejarah itu berhubungan dengan bagian dunia lainnya (Lieberman, 2003: xix).

Kajian sejenis yang lebih baru adalah yang dilakukan oleh Craig A. Lockard (2009) dalam bukunya yang berjudul Southeast Asia in World History. Buku ini menjelaskan bagaimana sejarah kawasan Asia Tenggara sebagai bagian integral dari sejarah kawasan-kawasan dunia lainnya dalam kerangka pandang yang disebut sebagai world history.

The encounters of Southeast Asians with peoples from other regions greatly influenced the states, religions, arts, and economies that developed. Like the Japanese, Southeast Asians borrowed ideas from others. Like the Chinese, Indians, and West Africans, they supplied valuable commodities, such as gold and spices, to the world. And like the Arabs, Indians, and Chinese, they transported trade goods around vast oceans. Themes such as borrowing and adaptation, migration and ethnic mixing, the diffusion of religions, maritime trade, Western expansion and colonialism, and the rise of the global economy linked Southeast Asia to world history (Lockard, 2009: 2-3).

Namun, tren yang agak positivistik dalam historiografi Barat di bawah pengaruh kuat dari pemikiran sejarah Fernand Braudel tersebut (yang sering disebut sebagai generasi pertama Mazhab Annales) kemudian mengalami arus balik pada 1980-an oleh kembalinya kecenderungan umum ke sejarah naratif. Ini adalah bagian dari 
perubahan dalam arus besar kajian linguistik dan budaya dalam ranah humaniora dan hilangnya kepercayaan umum pada gagasan 'kemajuan linear' dalam proses modernisasi. Dengan perubahan itu, tema, metode penelitian, dan tujuan penelitian sejarah turut bergeser pula. Alih-alih mencari pola dan struktur, para sejarawan era 1980-an ini ingin menemukan makna yang terkait dengan situasi-situasi konkret dari masa lalu. Di antara generasi kedua Mazhab Annales, sejarawan seperti George Duby dan Emanuel Le Roy Ladurie, misalnya, kurang peduli dengan sintesis besar tetapi lebih tertarik pada sejarah mentalitas pada tingkat mikro. Istilah seperti representasi, simbol, dan metafora menempati tempat sentral dalam penulisan sejarah sebagai 'kisah' itu. Pada titik ini, 'kebenaran' sastra dan sejarah menjadi terjalin erat. Generasi kedua dari Mazhab Amnnales tersebut kemudian mendeklarasikan pengertian penulisan-sejarah naratif sebagai "representasi khusus dari masa kini ketimbang sebagai terjemahan dari apa yang sebenarnya terjadi di masa lalu" (narrative history-writing to be a particular representation of the present rather than a rendering of what actually happened in the past). Pandangan ini dikembangkan melalui pemikiran pasca-modernis yang menarik dukungan dari kelompok minoritas di kalangan sejarawan profesional. Sekarang ini berbagai mata kuliah yang diampu dan pendekatan yang diterapkan oleh para sejarawan telah menjadi lebih terdiversifikasi daripada di periode sebelumnya (Houben, 2006: 143).

Sebagai contoh dari tren diversifikasi ini ialah apa yang telah dihimpun oleh Peter Burke dalam buku New Perspectives on Historical Writing (1991) yang berisi bab-bab tentang sejarah dari bawah (history from below), sejarah wanita, sejarah luar negeri, sejarah mikro, sejarah gambar 
dan sejarah tubuh. Daftar ini dapat diperluas dengan tema lain, mulai dari sejarah perkotaan hingga sejarah ekologis, dan pendekatan baru seperti menulis sejarah secara mundur dalam waktu (dari masa kini ke masa lampau) atau secara bersamaan dari berbagai sudut. Mengacu pada perkembangan dalam historiografi mutakhir ini, dapat dikatakan bahwa sejarah saat ini mencakup hampir semua aspek kehidupan manusia.

\section{Arah Baru dalam Kajian Sejarah Asia Tenggara}

Pada tahun 1999, dua puluh satu sejarawan pribumi Asia Tenggara bertemu di Penang, Malaysia untuk mengidentifikasi arena baru bagi sejarah Asia Tenggara. Thongchai Winachakul, pakar sejarah Asia Tenggara asal Thailand, mengajak mereka yang hadir untuk meninggalkan format lama sejarah nasional karena konfigurasi spasial bangsa semakin terancam dan kehilangan daya tariknya sebagai subjek historis. Sebaliknya, para sejarawan didesak untuk mulai menulis sejarah di area 'interstices' (interstisi, atau celah-celah, atau marjin, atau pinggirin, atau perbatasan), yakni "local history at the margins of nation and at the local sites of cultural productions in an era of globalization" (Houben, 2006: 152). Dengan panggilan baru ini, kajian sejarah lokal justru menjadi sangat penting di tengah proses globalisasi sekarang ini, tetapi kajiannya harus bersifat kontekstual dengan dengan dinamika sejarah global. Maksudnya, dinamika lokal yag dihasilkan dari studi sejarah lokal tersebut harus dapat ditempatkan dalam konteks besar dinamika sejarah global. Dengan kata lain, yang dimaksud Winachakul ialah suatu kajian sejarah yang mampu mengaitkan dinamika pada margin lokal dengan dinamika pada pola global. 
Himbauan Winachakul tersebut adalah sebuah agenda yang memungkinkan kajian sejarah Asia Tenggara melompat maju dan keluar dari relung ganda tradisional (spasial dan disiplin). Dalam historiografi Barat ada gerakan serupa yang menarik juga bagi para sejarawan Asia Tenggara, yaitu pendekatan komparatif yang untuk konteks Asia Tenggara sudah digunakan oleh Anthony Ried dalam Southeast Asia in the Age of Commerce maupun oleh Victor Lieberman dalam Strange Parallels: Southeast Asia in Global Context. Kajian yang berorientasi pada perbandingan antar-kawasan (intra-region) dapat memperkuat kesadaran akan kompleksitas di Asia Tenggara, jauh melampaui dikotomi yang sebelumnya sering menimbulkan perbedaan antara daratan (mainland) dan kepulauan (insular). Kajian sejarah regional yang komparatif juga memungkinkan dimensi lokal untuk dihubungkan dengan yang global, misalnya ketika mencari koneksitas antara Asia Tenggara dan Asia Selatan atau Timur tetapi juga antara Asia Tenggara dan Eropa (Houben, 2006: 152).

Arah baru sejarah Asia Tenggara 'pada interstisi' tadi, sebagaimana telah diberikan contohnya melalui karya Reid maupun Lieberman, sebenarnya telah dimulai oleh para eksponen Mazhab Annales sejak 1970an, hanya saja pada masa itu belum ada sejarawan pribumi Asia Tenggara yang menjadi penulisnya. Dalam perspektif interstisi ini, pada satu sisi kawasan Asia Tenggara menjadi bagian dari bidang sejarah dunia yang lebih luas dan semakin relevan, dan pada sisi lain sejarah marjin (history of margins) dan wilayah perbatasan semakin meningkat untuk memperlihatkan keterkaitan yang rumit antara lokal, regional, nasional, dan global (Houben, 2006: 154). 
Arah baru kajian sejarah Asia Tenggara itu bukan hanya terkait dengan perspektif komparatif antar-kawasan, tertapi juga terjadi perubahan dalam identifikasi periode-periode kajian. Di satu sisi, studi jangka panjang yang mencakup rentang waktu beberapa ratus tahun masih terus dilakukan; tetapi di sisi lain tumbuh pesat juga minat untuk mengkaji periode transisi yang memotong periodisasi tradisional. Salah satu contohnya adalah studi tentang periode 1930-an hingga 1950-an yang kini dapat dilihat sebagai periode tunggal dalam sejarah Asia Tenggara yang ditandai oleh ketidakstabilan besar dan rekonfigurasi sosial-ekonomi mendasar. Demikian juga periode abad keenam belas hingga kedelapan belas sebagai masa di mana pra-kolonial dan kolonial berbaur telah menarik perhatian banyak kalangan sejarawan Asia Tenggara generasi sekarang ini.

Seruan Winachakul kepada sejarawan pribumi Asia Tenggara tersebut tampaknya didasari oleh perkembangan yang positif di kalangan sejarawan probumi kawasan itu. Pasca Peraang Dunia II terjadi perluasan sistem pendidikan tinggi di Asia Tenggara yang telah memberikan dorongan untuk mempelajari sejarah Asia Tenggara oleh orang Asia Tenggara sendiri. Sekarang ini, dengan populasi lebih dari 600 juta orang, tumbuh keyakinan bahwa pengembangan masa depan pengetahuan mengenai sejarah Asia Tenggara akan ditentukan lebih banyak oleh para sejarawan Asia Tenggara itu sendiri. Keyakinan ini bukannya tanpa alasan. Sejak dasawarsa pertama tahun 2000-an sudah mulai ada usaha ke arah itu dan hasilnya adalah terbitnya sebuah buku berjudul $A$ New History of Southeast pada 2010 yang ditulis oleh para sejarawan pribumi Asia Tenggara yang berkolaborasi dengan sejarawan Barat-yakni Prof. 
M.C. Ricklefs dan Prof. Bruce Lockhart-yang sudah sangat lama berkecimpung di Asia Tenggara sehingga memungkinkan mereka untuk merasakan sebagai orang Asia Tenggara itu sendiri.

\section{PEMBAHASAN}

Karya monumental D.G.E. Hall, A History of South-East Asia, yang datang sepuluh tahun setelah berakhirnya Perang Dunia II, merupakan sebuah titik balik untuk mewujudkan perubahan dalam arah kajian Asia Tenggara yang telah mulai meretas jalannya sendiri pasca Perang Dunia II, dan menetapkan arena untuk pengembangan studi Asia Tenggara yang kemudian (Legge, 1992: 1-2). Dari sisi pendekatan, Hall telah mencoba untuk menjaga terhadap apa yang disebut sebagai pendekatan 'Eropasentris' dan 'India-sentris' yang sangat dominan dalam kajian sejarah Asia Tenggara di kurun waktu sebelum Perang Dunia II (Trager, 1956).

Meski karya monumental Hall tersebut berumur panjang, namun demikian dalam hal tema dan perspektif kajian tidaklah demikian. Kurang dari dua dasawarsa kemudian, karya Hall tersebut sudah mulai terasa menjadi ketinggalan zaman dilihat dari tema dan perspektif kajiannya. Dalam hal tema kajian, jika isu utama di kalangan sejarawan Asia Tenggara pada periode sebelum dan saat muncunya karya D.G.E. Hall didominasi oleh perdebatan mengenai sifat dan signifikansi pengaruh eksternal (India, Cina, Islam dan Eropa) pada masyarakat Asia Tenggara, pada periode 1960-an hingga awal 1980-an isu utamanya sudah bergeser ke tema lain. Perubahan ini sebenarnya sudah diawali oleh publikasi buku Indonesian Trade and Society: Essays in Asian Social and Economic History pada tahun 1955 yang merupakan terjemahan bahasa Inggris dari tesis doktor van Leur. Buku ini menarik perhatian para 
sejarawan Asia Tenggara karena membawa perdebatan ke arah yang berbeda. Sementara argumen-argumen sebelum 1955 lebih banyak memusatkan perhatian pada proses-proses 'Indianisasi' dan sejauh mana ia dibentuk-ulang oleh budaya-budaya lokal, debat baru dilakukan pada tingkat yang lebih luas, lebih umum, dan lebih konseptual. Itu berkaitan dengan gagasan 'otonomi' sejarah Asia Tenggara.

Secara metodologis, van Leur juga telah mengubah arah perhatian kajian sejarah Asia Tenggara dari fokus pada rincian bukti menuju gagasan kemandirian yang lebih umum. Dengan arah baru ini, jika pengaruh India harus dilihat sebagai pinjaman atau diserap oleh masyarakat Asia Tenggara selama periode sebelum kehadiran peradaban Islam dan Barat, pandangan itu memungkinkan untuk membangun penafsiran ihwal kemandirian yang berkelanjutan dan otoritas budaya lokal dari sejarah Asia Tenggara. Dengan itu pula, sejarah Asia Tenggara dapat dilihat sebagai subjek dalam dinamika internalnya sendiri, alih-alih sebagai objek dari tekanan eksternal (Legge, 1992: 23, 25-26).

Tema lain yang menonjol pada periode 1960-an hingga awal 1980-an adalah perihal kedatangan Islam ke Asia Tenggara dan dampaknya terhadap masyarakat di kawasan itu. Tema ini berkembang lebih lanjut menjadi salah satu tema utama di kalangan sejarawan Asia Tenggara dalam periode sesudah terbitnya karya Hall. Aspek menariknya ialah bahwa diskusi tema ini dilakukan dengan cara pandang yang berbeda dari perdebatan tentang Indianisasi sejarah Asia Tenggara. Bila gagasan tentang Indianisasi berfokus pada superioritas peradaban India dan pengaruhnya yang dominan terhadap sejarah kawasan Asia Tenggara, maka gagasan tentang 'Islamisasi' ini lebih menonjolkan terjadinya proses 
saling serap antara perdaban Islam dan kebudayaan lokal Asia Tenggara, khususnya di wilayah-wilayah Asia Tenggara kepulauan. Sebagai contoh, Azyumardi Azra (1994) dalam Jaringan Ulama Timur Tengah dan Kepulauan Nusantara Abad XVII dan XVIII mempelajari kamus biografi Arab untuk menentukan bagaimana ide-ide Islam di Timur Tengah ditransmisikan ke Kepulauan Indonesia. Peter Riddell melakukan hal yang sama terhadap sumber-sumber manuskrip dalam upayanya untuk menemukan risalahrisalah Islam dan teks-teks sastra apa saja yang ditransmisikan ke Asia Tenggara, sehingga membentuk sifat Islam di wilayah ini. Sementara itu, dengan melihat pergerakan orang dan barang, Huub de Jonge dan Nico Kaptein mempresentasikan koleksi esai yang menunjukkan peran pedagang Arab di Kepulauan Indonesia (Houben, 2006: 156).

Subjek diskusi lain yang juga semakin menarik perhatian para sejarawan adalah tentang karakter otoritas tradisional dan tatanan sosial-tentang penguasa dan dunia, negara dan tata negara. Pada 1960an dan awal 1970-an minat dalam kajian mengenai tatanan politik tradisional dan teori politik itu bermunculan sebagian dari fokus pada studi sejarah masa itu. Sejarawan masa itu menaruh perhatian yang cukup besar terhadap sejarah tatanan politik tradisional karena tema ini menyangkut kisah hidup orang banyak. Dalam kadar yang lebih kurang sama, perhatian para sejarawan juga ditujukan pada tema persoalan tatanan sosial dan otoritas di baliknya: perubahan sosial pada masyarakat petani dan gangguan-gangguan yang mereka alami, pemberontakan kaum petani, dan gerakan perlawanan atau bentuk-bentuk resistensi lainnya. Tema ini terkadang dilihat sebagai manifestasi awal dari pemberontakan nasionalis, tetapi semakin banyak para sarjana yang 
berfokus pada karakter milenarian gerakan-gerakan tersebut dan dalam cara mereka menggabungkan protes mereka dengan unsur-unsur kepercayaan dan praktik tradisional. Misalnya adalah gagasan dalam budaya Jawa mengenai Ratu Adil yang dapat memulihkan keharmonisan dan kemakmuran bagi masyarakat yang terganggu adalah elemen umum dalam gerakan-gerakan yang digambarkan oleh Sartono Kartodirdjo dalam upayanya untuk mengklasifikasikan berbagai jenis protes petani di Jawa (Legge, 1992: 32-34).

Perubahan-perubahan dalam kajian sejarah Asia Tenggara pada periode 1960-an hingga awal 1980-an tersebut kemudian menemukan puncaknya pada 1988 melalui karya monumental Anthony Reid, Southeast Asia in the Age of Commerce. Sejarawan Onghokham (2014: xiv), dalam kata pengantarnya terhadap buku itu, menyatakan bahwa meskipun sejarah total adalah suatu kajian sejarah peradaban yang meliputi semua aspek kemasyarakatan-dan bukan hanya politik-tetapi karya Reid tersebut bahkan agak mengabaikan aspek politik. Aspek-aspek yang menjadi perhatian Reid adalah, geografi, demografi, pakaian, pesta rakyat dan kerajaan, perumahan, material culture, makanan, seks, kedudukan wanita versus laki-laki, dan lainnya yang sejenis. Ini semua merupakan sejarab total yang membicarakan semua unsur masa lampau yang membentuk peradaban masyarakat di suatu kawasan. Asia Tenggara dalam gambaran Reid, sebagaimana dunia Mediteranian, merupakan kawasan geografis yang sangat terpisah dari kawasan sekitarnya yaitu India, Asia Timur, dan Pasifik.

Sedangkan sejarawan Asvi Warman Adam (2011: xiv) dalam kata pengantarnya terhadap jilid kedua buku Reid itu menyatakan bahwa 
sejarah total yang disusun oleh Ried tersebut juga, secara inheren, bersifat komparatif. Keunggulan pendekatan komparatif, menurut Asvi, sering mampu memperjelas sesuatu yang tampak kabur bila dilihat dalam konteks terbatas pada satu negara. Dalam buku Reid, itu terlihat jelas: kejayaan alat tukar perak, 'revolusi kemiliteran' (senjata api dan perahu bermeriam), kebangkitan dan kejatuhan komunitas pedagang asing, kecenderungan penguasa memeras warganya (dengan meminta sepersepuluh sampai sepertiga dari seluruh hasil tanah mereka). Reid juga menengarai kesejajaran di antara agama-agama baru dalam hubungannya dengan kesejahteraan, keberanian berperang, tulisan, dan penyembuhan. Upaya untuk mencocokkan pengembangan khas lokal dengan pola umum regional tentu menimbulkan berbagai pertanyaan, tetapi justru di sinilah terletak kekuatan buku Reid. Sebagaimana halnya karya Fernand Braudel, Mediterania dan Dunia Mediterania pada Masa Philip II, telah menjadi sebuah model bagi satu generasi sejarawan Eropa, Asia Tenggara dalam Kurun Niaga karya Reid ini juga menjadi model kajian sejarah total kawasan Asia Tenggara.

Melalui buku tersebut, Reid telah menerapkan prinsip-prinsip 'sejarah baru' Braudel dan Mazhab Annales untuk mempelajari Asia Tenggara selama periode kritis dari mana sejarah modern secara langsung diturunkan. Dalam buku ini, Reid tidak menitikberatkan prhatiannya pada kronologi berbagai peristiwa, tetapi memilih untuk mengungkapkan-melalui aspek-aspek keseharian dalam kehidupan masyarakat: kesejahteraan fisik, budaya material, organisasi sosial, dan festival dan hiburan-karakteristik umum dari beragam kelompok masyarakat yang ada di Asia Tenggara dan untuk selanjutnya 
menemukan struktur sosial yang khas di Asia Tenggara (Peters, 1990). Melalui karyanya itu pula, Reid telah membangun bangunan bersejarah yang memungkinkan para pembaca untuk memasuki dunia sejarah Asia tenggara yang kaya dokumentasi dengan penekanan yang konsisten pada konteks komparatif dan regional. Secara metodologis, Reid juga telah sedapat mungkin menggunakan sumber tekstual Asia Tenggara secara mengesankan, bekerja dari teks asli (terutama di kawasan Asia Tenggara kepulauan yang bahasa-bahasanya lokalnya ia kuasai), dan dari teks terjemahan untuk sumber-sumber dari Asiua tenggara daratan. Selain itu, ia juga telah menyisir sumber-sumber Eropa terbaru untuk periode yang dipilihnya (yaitu 1450-1680), termasuk sejumlah catatan berharga yang ditinggalkan oleh para pelancong, pedagang, dan tentara yang pernah mengunjungi Asia Tenggara.

Hanya berselang empat tahun kemudian, muncul karya sejenis tetapi ditulis secara lebih komprehensif, yaitu The Cambridge History of Southeast Asia yang disunting oleh Nicholas Tarling. Dalam resensinya terhadap buku ini, William H. Frederick mengatakan, "Di kawasan yang masih belum ada penulisan sejarahnya yang komprehensif maupun menggunakan pendekatan sejarah yang cukup baru, The Cambridge History adalah sebuah milepost di sepanjang jalan, suatu prestasi yang pantas mendapat pengakuan lebih dari sekadar kata-kata pujian" (Frederick, 1994). Sedangkan sejarawan Michael Aung-Thwin (1994) dalam resensinya terhadap buku tersebut mengatakan bahwa pendekatan yang ditempuh buku ini adalah dengan menggabungkan peristiwa dan 'struktur' yang ditempatkan dalam konteks historis yang oleh Fernand Braudel disebut 'longue duree'. Melalui strategi ini, karya ini mampu 
menjawab beberapa masalah teoretis dan metodologis yang paling mendesak di bidang sejarah Asia Tenggara sejak awal berdirinya hampir lima puluh tahun yang lalu.

Dasawarsa 1990-an juga mencatat perubahan signifikan lainnya dalam tema dan perspektif kajian sejarah Asia Tenggara. Dengan gempuran paradigma narrativisme dan pasca-strukturalisme dalam ilmuilmu sosial-humaniora sejak dasawarsa 1980-an, dalam satu dasawarsa berikutnya historiografi Asia Tenggara juga turut terpengaruh dan mengalami pembaruan tema-tema dengan menempatkan 'budaya' dan 'mentalitas' sebagai pusat perhatian. Sejarah monumental Jawa oleh Denys Lombard, yaitu tiga jilid tebal buku bertajuk Nisa Jawa Silang Budaya (1996), yang sangat mirip dengan karakteristik publikasi generasi kedua dari kelompok Annales, merupakan kajian sejarah yang mencoba mengungkap lapisan budaya yang mendasari mentalitas kompleks masyarakat Pulau Jawa dalam kurun waktu tiga lapisan gelombang peradaban: masa klasik Hindu-Budha, era perkembangan Islam, dan periode kolonialisme Barat. Karya Frances Gouda (2007 [1995]), Dutch Culture Overseas, juga menampilkan karakteristik serupa: mengungkapkan bagaimana identitas budaya Belanda yang bersandar pada kebebasan sipil dan netralitas dalam konteks kolonialisme akhir diubah menjadi mentalitas superioritas rasial. Studi lain yang menarik tentang transfer budaya dalam konteks representasi modernitas oleh elite kerajaan Thailand sekitar awal abad kedua puluh, telah diajukan oleh Maurizio Peleggi. Tetapi, teori pasca-modernis hanya memengaruhi sebagian karya sejarawan Asia Tenggara (Houben, 2006: 146). 
Perkembangan mutakhir dalam historiografi Asia Tengara ditandai dengan terbitnya buku A New History of Southeast pada 2010. Dalam resensinya terhadap buku ini, Patrick Jory (2011) mengatakan bahwa sampai taraf tertentu buku tersebut telah merepresentasikan tren yang diserukan oleh Prof. Winachakul mengenai penulisan sejarah Asia Tenggara pada area 'interstisi', yaitu sebuah "buku yang ditulis di Asia Tenggara oleh para sejarawan yang tinggal di sana". Lebih jauh, Ricklefs (2013: xviii) dalam kata pengantarnya mengatakan bahwa para penulis buku A New History of Southeast Asia tersebut mencoba membuat karya yang lebih dari sekadar narasi. Memang benar bahwa adanya narasi yang faktual dan umum mengenai sejarah Asia Tenggara adalah sebuah kemestian, sesuatu yang tidak dapat mereka hindari. Buku yang dimaksudkan untuk memperbaraui karya monumental D.G.E Hall itu juga sulit untuk menghindarkan dirinya dari menyediakan narasi yang dimasukkan ke dalam segmen-segmen menurut negara, demi menghasilkan buku yang enak dibaca. Namun demikian, lanjut Ricklefs, “Kami ingin melangkahi batas segmen-segmen ini sepanjang kami bisa melakukannya untuk menunjukkan isu-isu dan tema-tema luas yang tersebar di seluruh kawasan, juga isu dan tema yang mendominasi dalam historiografi-historiografi tertentu."

Asia Tenggara, sebagaimana telah terbukti dalam seluruh kajian mengenai kawasan ini, adalah memang kawasan yang sepanjang lintasan sejarahnya telah menjadi jalur lalu lintas internasional sehingga selalu terbuka pada berbagai pengaruh dan inspirasi dari luar yang kemudian diubah oleh orang-orang Asia Tenggara agar sesuai dengan kepentingan mereka sendiri. Itu sebabnya, para penulis buku A New History of Southeast 
ini telah mencoba semua kemungkinan yang mampu mereka lakukan untuk menempatkan sejarah pribumi kawasan ini dalam konteks internasional.

Terkait erat dengan karakteristik lintas-budaya dalam lintasan panjang sejarah Asia Tenggara itu, dan perubhan-perubahan dalam tema dan perspektif kajiannya, tuntutan kualifikasi bagi para sejarawan kawasan ini juga harus terus disesuaikan. Ricklefs (2013: xix-xx) mengemukakan analisisnya bahwa sekarang ini kualifikasi yang diharapkan dari seorang sejarawan Asia Tenggara telah menjadi semakin berat. Para sejarawan Asia Tenggara harus menguasai bahasa-bahasa pribumi serta bahasa-bahasa lain yang digunakan untuk menulis sumbersumber asing yang relevan. Kemampuan berpikir interdisipliner juga semakin dituntut, terutama dengan disiplin ilmu antropologi, untuk memperkaya informasi bagi bidang kajian sejarah Asia Tenggara. Para sejarawan Asia Tenggara didorong untuk mengajukan pertanyaanpertanyaan tentang struktur sosial, hubungan ekonomi, kepercayaan dan nilai, selain tentang kejadian-kejadian, penyebab dan dampaknya. Mereka dikondisikan untuk mencoba memahami seperti apa rasanya menjadi orang Asia Tenggara di suatu tempat di masa tertentu.

\section{KESIMPULAN}

Selama lima puluh tahun terakhir, jumlah, kualitas, dan ragam bukubuku sejarah mengenai Asia Tenggara terus meningkat. Setelah Perang Dunia II banyak muncul literatur sejarah politik yang mencoba menjelaskan kebangkitan negara-negara Asia Tenggara yang baru merdeka. Kemudian, sejak dasawarsa 1960-an, fokus tematis utama bergeser ke arah masalah ekonomi dan sosial yang melihat proses jangka 
panjang yang menjelaskan mengapa sebagian besar negara-negara Asia Tenggara masih belum berkembang, yang dicirikan oleh kesenjangan sosial yang besar di seluruh kawasan ini. Pada dasawarsa 1980-an, dengan timbulnya linguistik dan perubahan budaya dalam ilmu-ilmu sosial, sejarawan di wilayah ini semakin beralih ke studi tentang pembentukan identitas dalam kurun waktu yang berbeda-beda, memulai analisis diakronis mengenai mentalitas, representasi, dan wacana pengetahuan lokal.

Tidak hanya tema yang bergeser, cara pandang atau persepktif dalam penelitian sejarah Asia Tenggara juga telah bergeser. Jika studi sejarah pada 1950-an dan 1960-an mengutamakan kelanjutan atas kajiankajian dari periode sebelumnya, sebelum Perang Dunia II, kini perspektifnya telah berbeda secara cukup mendasar. Memang periode yang dikaji masih relatif sama, yaitu Asia Tenggara masa pra-kolonial dan kolonial, tetapi cara melihat dinamikanya sekarang dirasakan dari perspektif Asia (Tenggara)-sentris yang menempatkan dinamika Asia Tenggara di depan, bukannya melihat perubahan-perubahan di dalam masyarakat Asia Tenggara sebagai berasal hanya dari stimulus India, Cina, Islam, dan Barat.

Pergeseran tema dan perspektif penulisan sejarah di Asia Tenggara pada dasawarsa 1980-an tersebut juga disertai dengan peningkatan dalam penggunaan teori oleh para sejarawan yang mereka ambil dari disiplin 'tetangga' (ilmu politik, sosiologi, antropologi, sastra, dan kajian budaya). Pada saat yang sama, para sarjana yang menekuni studi Asia Tenggara yang berasal dari disiplin-disiplin di luar sejarah itu semakin banyak terlibat dalam pembuatan catatan sejarah untuk kepentingan studi 
mereka. Dengan demikian, secara yang tidak langsung para sejarawan dan mahasiswa dari disiplin lain secara bertahap berkumpul dan berkolaborasi untuk menghasilkan apa yang bisa disebut sebagai studi regional Asia Tenggara yang benar-benar bersifat transdisipliner dan komparatif.

Penelitian ini berusaha untuk merangkum perkembangan penulisan sejarah yang mencirikan dan membentuk sejarah Asia Tenggara sejak terbtitnya buku D.G.E. Hall ( $A$ History of South-East Asia) pada 1955 hingga terbitnya buku pembaharu (A New History of Southeast) atas karya Hall itu. Secara umum dapat disimpulkan bahwa perkembangan dalam kajian sejarah Asia Tenggara masih mengikuti tren dalam sejarah Barat, dan ini yang justru menjadi penyebab mengapa sejarah Asia Tenggara masih hanya menempati ceruk kecil dalam wacana sejarah global. Tetapi tren baru yang muncul pada akhir dasawarsa 1990-an mendorong penulisan sejarah Asia Tenggara pada area 'interstisi', yang menghubungkan sejarah kawasan lokal Asia Tenggara dengan konteks historis globalnya. Metodologi sejarah komparatif tampaknya paling sesuai untuk aplikasi dalam konteks ini. Oleh karena itu, masa depan sejarah Asia Tenggara terletak pada konektivitas disiplinnya sendiri dengan berbagai disiplin ilmu sosial-humaniora lainnya untuk membangun jembatan kajian transdisipliner yang melampaui batasan ruang-temporalnya.

\section{DAFTAR PUSTAKA}

[1] Abdullah, Taufik. (1997). "Ke Arah Penulisan Sejarah Pemikiran Islam di Asia Tenggara: Sebuah Pelancongan Bibliografis", dalam Taufik Abdullah dan Edi Sedyawati (penyunting) Sejarah Indonesia: Penilaian Kembali Karya Utama Sejarawan Asing, Depok: Pusat 
Penelitian Kemasyarakatan dan Budaya, Lembaga Penelitian, Universitas Indonesia.

[2] Adam, Asvi Warman. (2011). 'Pengantar: Merintis Sejarah Total Asia Tenggara'. Dalam Anthony Reid, Asia Tenggara dalam Kurun Niaga 1450-1680, Jilid 2: Jaringan Perdagangan Global Asia Tenggara. Jakarta: Obor. (Judul asli: Southeast Asia in the Age of Commerce 14501680, Expansion and Crisis, 1993, Yale University).

[3] Aung-Thwin, Michael \& Kenneth R. Hall. (2011). 'Introduction', dalam Michael Arthur Aung-Thwin \& Kenneth R. Hall (editors) New Perspectives on the History and Historiography of Southeast Asia: Continuing Explorations. Oxon: Routledge.

[4] Aung-Thwin, Michael. (1994). 'The Cambridge History of Southeast Asia. Volume I- From Early Times to c. 1800' (resensi buku), dalam The Journal of Asian Studies, Vol. 53, No. 2 (May, 1994), pp. 653-657.

[5] Azra, Azyumardi. (1994). Jaringan Ulama Timur Tengah dan Kepulauan Nusantara Abad XVII dan XVIII. Bandung: Mizan.

[6] Burke, Peter. (1991). New Perspectives on Historical Writing. Cambridge: Cambridge University Press.

[7] Frederick, William H. (1994). 'The Cambridge History of Southeast Asia. Volume II: The Nineteenth and Twentieth Centuries'. by Nicholas Tarling (resensi buku), dalam The Journal of Asian Studies, Vol. 53, No. 2 (May, 1994), pp. 658-660.

[8] Gouda, Frances. (2007). Dutch Cultures Overseas: Praktik Kolonial di Hindia Belanda, 1900-1942. Jakarta: Serambi. (Edisi asli buku ini adalah dalam bahasa Inggris berjudul Frances Gouda, Dutch Culture Overseas: Colonial Practice in the Netherlands Indies, 1900-1942 [Amsterdam: Amsterdam University Press, 1995]).

[9] Hall, D.G.E. (1955). A History of South-East Asia. London: Macmillan.

[10] Houben, Vincent. (2006). 'Southeast Asian History: The Search for New Perspectives', dalam Cynthia Chou dan Vincent Houben (editors), Southeast Asian Studies: Debates and New Directions. Singapore: Institute of Southeast Asian Studies.

[11] Jory, Patrick. (2011). 'A New History of Southeast Asia' (resensi buku), dalam Journal of the Malaysian Branch of the Royal Asiatic Society Volume 84, Part 2, September 2011, No. 301 pp. 122-126. 
[12] Legge, John D. (1992). 'The Writing of Southeast Asian History', dalam Nicholas Tarling (Editor), The Cambridge History of Southeast Asia. Vol. 1. From early times to c. 1800. Cambridge: Cambridge University Press.

[13] Lieberman, Victor. (2003). Strange Parallels: Southeast Asia in Global Context, c. 800-1830, Volume I: Integration of the Mainland. Cambridge: Cambridge University Press.

[14] Lockard, Craig A. (2009). Southeast Asia in World History. New York: Oxford University Press.

[15] Lombard, Denys. (1996). Nusa Jawa: Silang Budaya (Terdiri dari tiga jilid: [1] Batas-batas Pembaratan, [2] Jaringan Asia, dan [3] Warisan Kerajaan-kerajaan Konsentris. Jakarta: Gramedia. (Edisi asli buku ini adalah dalam bahasa Perancis, berjudul Le Carrefour Javanais. Essai historique d'histoire globale [Paris, Éditions de l'EHESS, 1990]).

[16] Onghokham. (2014) (cetakan ketiga). 'Pengantar: Ilmu Sejarah dan Kedudukan Sentralnya' (Pengantar), dalam Anthony Reid, Asia Tenggara dalam Kurun Niaga 1450-1680, Jilid 1: Tanah di Bawah Angin. Jakarta: Obor. (Judul asli: Southeast Asia in the Age of Commerce 14501680, Volume One: The Lands Below the Winds, 1988, Yale University).

[17] Peters, Joseph. (1990). 'Southeast Asia In The Age Of Commerce, 1450-1680 Volume 1: The Lands Below the Wind' by Anthony Reid (resensi buku), dalam Journal of the Malaysian Branch of the Royal Asiatic Society, Vol. 63, No. 1 (258) (1990), pp.129-131.

[18] Reid, Anthony. (2016). 'Foreword', dalam Ooi Keat Gin and Hoàng Anh Tuấn (editors), Early Modern Southeast Asia, 1350-1800. Oxon: Routledge.

[19] Reid, Anthony. (2011). 'Pendahuluan', dalam Anthony Reid, Asia Tenggara dalam Kurun Niaga 1450-1680, Jilid 2: Jaringan Perdagangan Global Asia Tenggara. Jakarta: Obor. (Judul asli: Southeast Asia in the Age of Commerce 1450-1680, Expansion and Crisis, Copyright $\odot 1993$ by Yale University), hlm. xxi.

[20] Ricklefs, M.C. (2013). 'Kata Pengantar', dalam M.C. Riklefs, Bruce Lockhart, Albert Lau, Portia Reyes, dan Maitrii Aung-Thwin, Sejarah Asia Tenggara: Dari Masa Prasejarah sampai Kontemporer. Depok: Komunitas Bambu. 
[21] Tarling, Nicholas. (1978). 'Southeast Asia: A History', by Lea E. Williams (resensi buku), dalam Pacific Affairs, Vol. 51, No. 1 (Spring, 1978), pp. 145-147.

[22] Tarling, Nicholas. (1992). 'Preface', dalam Nicholas Tarling (editor), The Cambridge History of Southeast Asia. Vol. 1. From early times to c. 1800. Cambridge: Cambridge University Press, hlm. xiii- xiv.

[23] Trager, Frank N. (1956). A History of South-East Asia, by D.G.E. Hall (resensi buku). Dalam The Far Eastern Quarterly, Vol. 15, No. 3 (May, 1956), pp. 433-438. 